3. Gustafsson A, Arnrup K, Broberg AG, Bodin L, Berggren U. Child dental fear as measured with the Dental Subscale of the Children's Fear Survey Schedule: The impact of referral status and type of informant (child versus parent) Community Dentistry and Oral Epidemiology. 2010;38:256-266.

4. Klingberg G. Dental anxiety and behavior management problems in paediatric dentistry - A review of background factors and diagnostics. European Archives of Paediatric Dentistry. 2008;9 (Suppl 1):11-15.

5. Versloot J, Veerkamp JSJ, Hoogstraten J. Dental anxiety and psychological functioning in children: Its relationship with behaviour during treatment. European Archives of Paediatric Dentistry. 2008;9(Suppl. 1):36-40.

DOI https://doi.org/10.30525/978-9934-588-81-5-2.55

\title{
ПРОБЛЕМА АЛЕРГІЧНОЇ ЗАХВОРЮВАНОСТІ У НАСЕЛЕННЯ ЕКОЛОГО-НЕБЕЗПЕЧНОГО РЕГІОНУ
}

\author{
Павленко О. I. \\ кандидат медичних наук, \\ завідувач лабораторії промислових аерозолів \\ ДУ «Украйнський науково-дослідний інститут промислової медиџини» \\ Орехова О. В. \\ кандидат медичних наук, \\ завідувач лабораторії промислового мікроклімату \\ та фізіології теплообміну \\ ДУ «Украӥнський науково-дослідний інститут промислової медицини» \\ м. Кривий Ріг, Дніпропетровська область, Украӥна \\ Вступ. Від алергічного риніту у світі страждає 4-10\% населення \\ (600 млн. осіб), у країнах Європи 3,2-19,6 \% [1, с. 117; 2, с. 556; \\ 3 , с. 7]. В Україні розповсюдженість алергічних захворювань склада- \\ ють 15-30 \%, що супроводжується втратою працездатності хворими в \\ період загострення хвороби, прогресуючим характером її перебігу та \\ формуванням бронхіальної астми [4, с. 29]. Стан техногенного забру- \\ днення атмосферного повітря впливає на агресивність пилкових алер- \\ генів, що сприяє зростанню захворюваності на поліноз у населення \\ еколого-небезпечного регіону [1, с. 116].
}


Матеріали та методи. Дослідження проводились на базі лаборатоpiї біохімії ДУ «УкрНДІпроммед» шляхом визначення концентрації $\operatorname{IgE}$ стандартним імуноферментним аналізом з використанням аналізатору імуноферментних реакцій MULTISCAN+Plus. В ході дослідження дотримувалися етичні та юридичні принципи відповідно до Гельсінської декларації Всесвітньої медичної асоціації. Всього було досліджено 159 зразків крові у осіб віком від 32,7 до 42,6 років (середній вік обстежених складав $39,4 \pm 1,9$ років) обох статей, що постійно проживають у різних районах міста Кривий Ріг.

Мета досліджень - аналіз рівня захворюваності на алергічну патологію в залежності від рівня забруднення атмосферного повітря у мешканців еколого-небезпечного регіону.

Результати та їх обговорення. В результаті досліджень встановлено, що показники IgE коливаються від 35 до $225 \mathrm{MO} /$ мл. Серед загальної кількості обстеженого населення м. Кривий Ріг у 45,3 \% осіб виявлено вміст IgE, що перевищував нормативні рівні. Середне значення рівня IgE становило $313,5 \pm 28,8 \mathrm{MO} / \mathrm{Mл}(\mathrm{M} \pm \mathrm{m})$, причому медіана складала 190 МО/мл Q25-85 МО/мл, Q75-1100 МО/мл.

Частота виявлення підвищених рівнів IgE представлена на рис. 1.

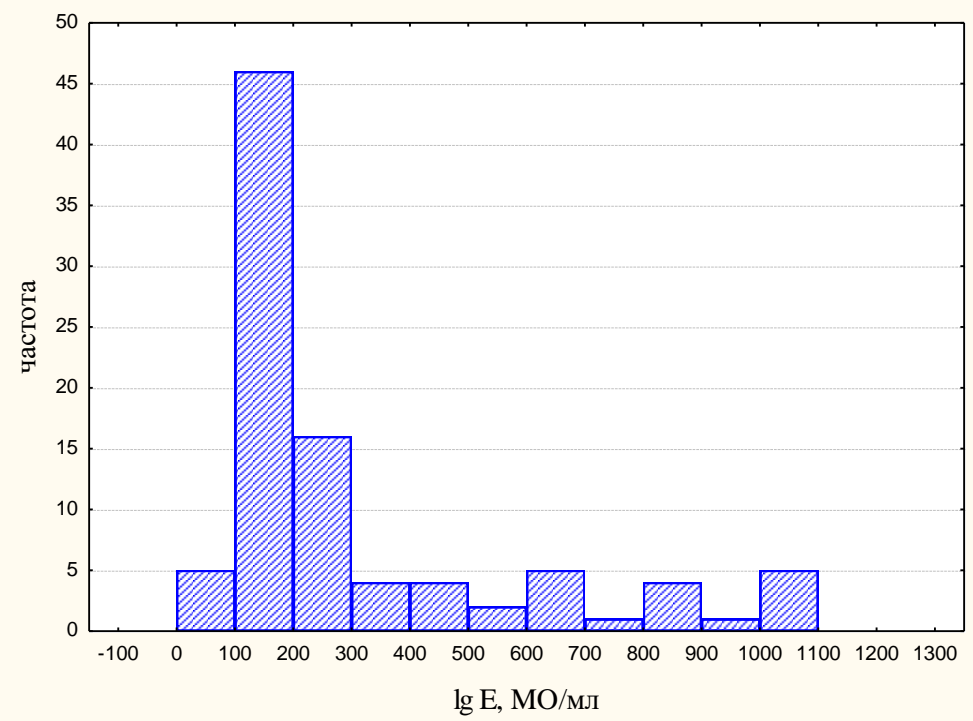

Рис. 1. Частота виявлення підвищених рівнів IgE 
Серед досліджених зразків крові найменший середній рівень концентрації $\operatorname{IgE}$ було виявлено у населення Тернівського району, а ймовірність підвищеного його значення відповідала загальноукраїнським даним для здорового населення, тому Тернівський район було вибрано у якості контрольної групи.

Середній вік осіб, у яких визначались рівні IgE, що не перевищували нормативні значення становив $42,6 \pm 3,0$ роки.

Середнє значення рівня $\operatorname{IgE}$ становило 41,7 $\pm 2,2 \mathrm{MO} / \mathrm{M}$ ( $(\mathrm{M} \pm \mathrm{m})$, причому медіана становила 40 МО/мл Q25-15 МО/мл, Q75-76 МО/мл.

Частота появи в аналізах значень, що не перевищують нормативні рівні представлена на рис. 2.

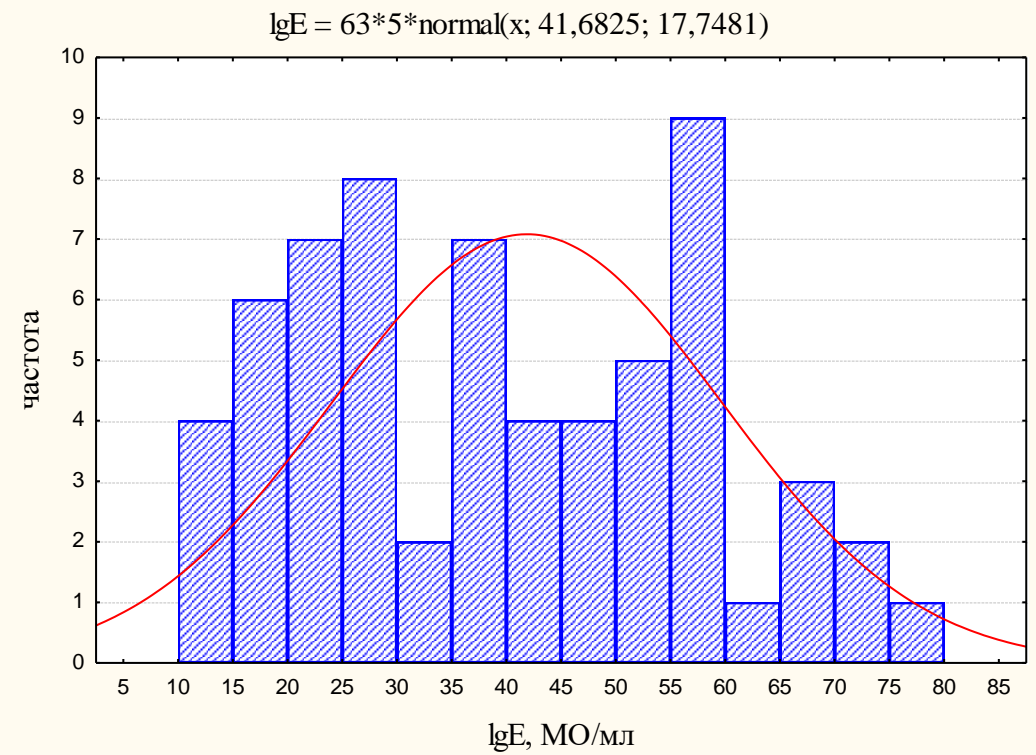

Рис. 2. Частота виявлення IgE серед здорових паціснтів

Таким чином, має місце тенденція, що обстежені особи, які мали підвищені рівні IgE були молодшого віку, ніж особи у яких рівні $\operatorname{IgE}$ не перевищували нормативних значень. Така ситуація $\epsilon$ характерною для районів, де зареєстровані більш високі рівні забруднення навколишнього середовища. Тому, для більш детального аналізу та встановлення залежності між районом проживання та рівнем IgE, проведено аналіз за адміністративними районами м. Кривий Ріг. 
Так, найвищі рівні показників IgE було виявлено у осіб, які мешкають у Довгинцівському районі (середнє значення IgE становить 318,75 МО/мл), Центрально-міському районі (середнє значення $\operatorname{IgE~-~272,5~MO/мл)~та~Саксаганському~районі~(середне~значення~}$ $\operatorname{IgE}-174,3 \mathrm{MO} /$ мл), тобто тих районах, які знаходяться у безпосередній близькості до розташування металургійного комбінату ПАТ «АрселорМіттал Кривий Ріг».

Одночасно з тим, концентрація IgE у мешканців Тернівського району становила 112,4 МО/мл.

Для отримання більш детальної інформації про алергічні реакції, необхідно враховувати саме перевищення нормативних рівнів, а не тільки середнє значення показників, тому до аналізу було залучено значення Percentile 75 \%, які наведено у таблиці 5.6:

Таблиця 1

Рівні концентрацій IgE у населення м. Кривий Ріг

\begin{tabular}{|c|c|c|c|}
\hline Райони м. Кривий Piг & Median & Percentile 25 \% & Percentile 75 \% \\
\hline Металургійний & 65,0 & 20,0 & 110,0 \\
\hline Довгинцевський & 97,5 & 45,0 & 592,5 \\
\hline Покровський & 60,0 & 40,0 & 180,0 \\
\hline Саксаганський & 55,0 & 30,0 & 220,0 \\
\hline Тернівський & 55,0 & 25,0 & 110,0 \\
\hline Центрально-міський & 160,0 & 115,0 & 430,0 \\
\hline
\end{tabular}

При проведені кореляційно-регресійного аналізу встановлено, що найбільші відхилення від норми корелюють з концентрацією пилу в повітрі міста $\mathrm{r}=0,5(\mathrm{p}<0.05)$, коефіцієнт детермінації $25 \%$ ), з концентрацією $\mathrm{NO}_{2}(\mathrm{r}=0,56(\mathrm{p}<0.05)$, коефіцієнт детермінації $31 \%)$, з концентрацією $\mathrm{CO}(\mathrm{r}=0,52(\mathrm{p}<0,05)$, коефіцієнт детермінації $27 \%)$, з концентрацією $\mathrm{NH}_{3}(\mathrm{r}=0,73(\mathrm{p}<0,05)$, коефіцієнт детермінації $53 \%)$, з максимально разовими концентраціями викидів хімічних речовин в атмосферне повітря $(\mathrm{r}=0,56(\mathrm{p}<0,05)$, коефіцієнт детермінації $31 \%)$.

Висновки. Таким чином встановлено, що рівні концентрацій IgE та їх відхилення від нормативних значень в крові населення м. Кривий Ріг залежить від територіального розташування місця проживання та відстані від джерел забруднення атмосферного повітря шкідливими хімічними речовинами, такими як пил, окиси азоту, вуглецю, аміаку та ін.

При аналізі алергічної патології встановлено, що найменший середній рівень концентрації IgE було виявлено у населення Тернівського району. найвищі рівні показників $\operatorname{IgE}$ було виявлено у осіб, які меш- 
кають у Довгинцевському районі (середне значення $\operatorname{IgE}$ становить 318,75 МО/мл), Центрально-міському районі (середнє значення $\operatorname{IgE~-~272,5~MO/мл)~та~Саксаганському~районі~(середнє~значення~}$ $\operatorname{IgE}-174,3 \mathrm{MO} /$ мл), тобто тих районах, які знаходяться у безпосередній близькості до розташування металургійного комбінату ПАТ «Арселор Міттал Кривий Ріг».

Перспективи подальших досліджень. Результати, які були отримані під час аналізу алергічної захворюваності, можна розглядати як вихідні дані для визначення екологічного ризику, що дозволить проводити динамічний санітарно-гігієнічний моніторинг за забрудненням атмосферного повітря від стаціонарних джерел та станом здоров'я працюючого населення еколого-небезпечного регіону.

\section{Лiтература:}

1. Дитятковская Е. М., Белецкая С. В. Динамика показателей цитокинового профиля il-4и ifn- $\gamma$ под влиянием комбинированной аллерген-специфической иммунотерапии (асит) у больных с полинозом и сочетанной сенсибилизацией к пыльцевым и бытовым аллергенам. Медичні перспективи. 2020. Т. 25, № 1. С. 116-121.

2. Jutel M., Agache I., Bonini S. International consensus on allergy immunotherapy. J Allergy Clin Immunol. 2015. Vol. 136. P. 556-568.

3. Хаитов М.Р., Намазова-Баранова Л.С., Ильина Н.И., Курбачёва O.M., Bachert C., Hellings P.W., Pfaar O., Schunemann H.J., Wallace D., Bedbrook A., Czarlewski W., Bousquet J. ARIA 2019: алгоритмы оказания помощи при аллергическом рините в России. Российский аллергологический журнал. 2020. № 1 (70). С. 7-22. https://doi.org/10.36691/RAJ.2020.17.1.001

4. Корецкая С. В., Дитятковська С. М. Особливості пилкової сенсибілізації у хворих на поліноз у місті Дніпро. Астма та алергія. 2019. № 3. C. 29-34. DOI: 10.31655/2307-3373-2019-3-29-34 